\title{
2軸応力の影響を考慮した主桁・横林交差部 の疲労寿命評価法の提案
}

\author{
森 猛1・平山 繁幸 2 ・香川 拓也3 \\ 1正会員 法政大学教授 都市環境デザイン工学科（テ162-0843 東京都新宿区市谷田町2-33） \\ E-mail: mori@k.hosei.ac.jp \\ 2正会員 株式会社東京鐵骨橋梁 技術開発部（ ( 302-0038 茨城県取手市下高井1020番地） \\ E-mail: Shigeyuki_Hirayama@ttk-corp.co.jp
}

3東京都 建設局第二建設事務所（†143-0016東京都大田区大森北5-11-5）（研究当時 : 法政大学大学院）

\begin{abstract}
鋼多主I桁橋の中桁ウェブと横桁フランジの交差部は，主桁作用による主桁ウェブ応力と荷重分配作用 による横桁フランジ応力が作用する2軸応力状態となることが多い. 著者らは疲労強度に対する2軸応力の 影響を評価するために応力増加係数を提案した。 すなわち, 公称応力範囲に応力増加係数を乗じ, これを 1軸荷重下で得られている疲労強度と比較する方法である.しかし，これまでの研究で対象とした交差部 の寸法と形状は限られており，実際の交差部の疲労寿命評価を行うためには，さらに検討が必要である. 本研究では, 板厚と溶接形状が応力増加係数に及ぼす影響を明らかにするためにFEM解析と疲労試験を行 った．それらの結果を基に，2軸応力の影響を考慮した主桁・横桁交差部の疲労寿命評価法を提案した.
\end{abstract}

Key Words : bi-axial stress, joints of main girder web and lateral girder flange, fatigue design

\section{1. はじめに}

鋼多主I枌橋の主桁（中桁）ウェブと横桁下フランジ の交差部（以下，交差部）では，図-1に示すように，ま わし溶接部の主桁ウェブ側止端部と横林フランジ側止端 部から疲労き裂が発生する可能性が高いとされている1). この部分は，主桁作用による主桁ウェブ応力に加えて, 荷重分配作用による横桁フランジ応力が作用する2軸応 力状態となることが多い.

著者らは，交差部の疲労強度に対する2軸応力の影響 について, 以下のように検討してきた. まず，横桁フラ ンジが取り付けられた主桁ウェブの疲労強度に対する横 桁フランジ応力の影響を明らかにする目的で，図-2に示 すモデル試験体を用いた疲労試験と応力解析を行った2). その結果，横桁フランジ応力が作用することにより主桁 ウェブの疲労寿命は減少し，その主因は横林フランジ応 力による主桁ウェブ側止端部の応力集中の増加にあると した. また, 応力解析において, 1軸応力下の溶接止端 近傍の応力分布と 2 軸応力下の応力分布がほぼ平行とな ることから，1軸応力下の応力分布に係数（応力増加係 数と呼ぶ）を乗じることで2軸応力が疲労強度に及ぼす 影響を整理できると考えた。
次に，主桁ウェブに取り付けられた横桁フランジの疲 労照査を行う際にモデル化される十字溶接継手と文献 2）で用いたモデル試験体の疲労試験を行うことにより， 試験体形状の違いが疲労強度に及ぼす影響について検討 しだ． FEM解析では，十字継手，モデル試験体ともに 主板端部で応力集中が生じていた．応力集中係数はモデ ル試験体の方が高かったため, 疲労試験においてもモデ

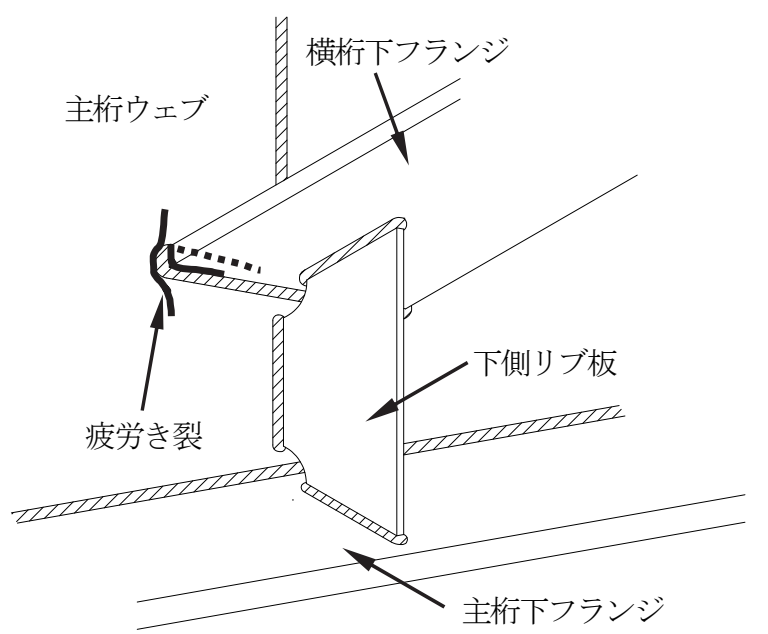

図-1 疲労損傷の例 ${ }^{1)}$ 


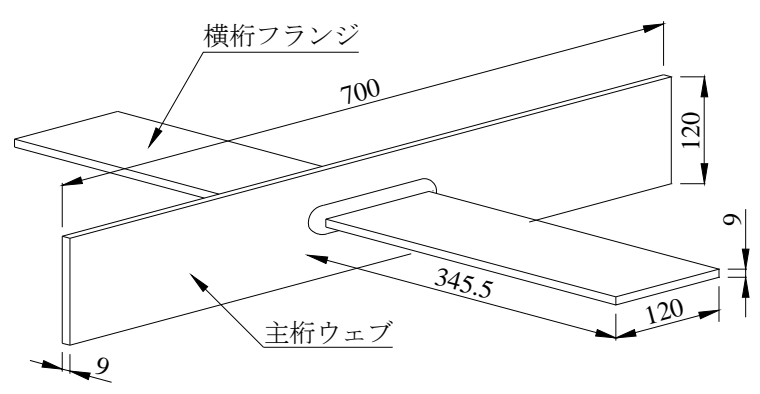

図-2 試験体形状

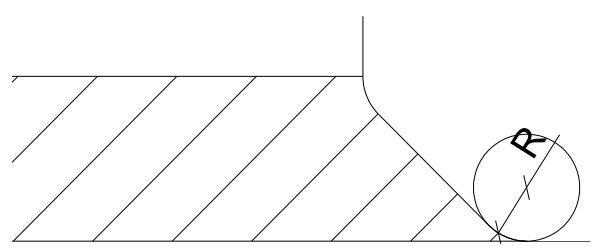

(a) 止端曲率半径

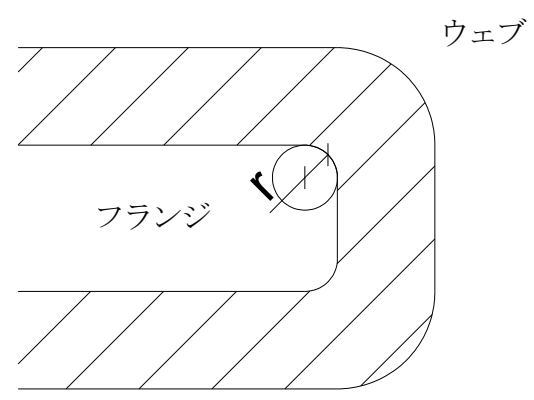

(b) 面取り半径

図-3＼cjkstart止端曲率半径および面取り半径の定義

儿試験体の方が疲労強度が低いと予想された。しかし， モデル試験体の主板角部（以下，横析フランジコーナー 部）は溶接により丸みを帯びていたため，実際には両者 の応力集中係数に大きな差はなく, 疲労強度は同程度で あった。

文献4）では，交差部の横桁フランジ側止端部に着目 し, 主桁ウェブ応力が横桁フランジの疲労強度に及ぼす 影響は横桁フランジ応力が主桁ウェブの疲労強度に及ぼ す影響よりも大きいこと，横桁フランジの疲労強度も応 力増加係数で評価できることを示した.

文献2)と4)では，以下の式で応力増加係数を与えてい る.

主林ウェブ $\quad \alpha=0.046 \beta+1$

$\alpha:$ 主桁ウェブの応力増加係数

$\beta:$ 横桁・主桁応力比 (横桁フランジ公 称応力 /主桁ウェブ公称応力)

横林フランジ $\quad \alpha^{\prime}=0.651 \gamma+1$

$\alpha^{\prime}:$ 主桁ウェブの応力増加係数

$\gamma:$ 主桁・横桁応力比 (主桁ウェブ公称

応力 / 横桁フランジ公称応力) 表-1＼cjkstart解析モデル（シリーズ I）

\begin{tabular}{|c|c|c|c|}
\hline $\begin{array}{c}\text { モデル } \\
\text { 名称 }\end{array}$ & $\begin{array}{c}\text { 主桁ウェブ厚 } t_{w} \\
(\mathrm{~mm})\end{array}$ & $\begin{array}{c}\text { 横桁フランジ厚 } t_{f} \\
(\mathrm{~mm})\end{array}$ & $\begin{array}{c}\text { 板厚比 } \\
t_{f} t_{w}\end{array}$ \\
\hline $\mathrm{T} 0909$ & 9 & 9 & 1.00 \\
\hline $\mathrm{T} 0911$ & 9 & 10.5 & 1.17 \\
\hline $\mathrm{T} 0912$ & 9 & 12 & 1.33 \\
\hline $\mathrm{T} 0914$ & 9 & 14 & 1.56 \\
\hline $\mathrm{T} 0916$ & 9 & 16 & 1.78 \\
\hline $\mathrm{T} 0918$ & 9 & 18 & 2.00 \\
\hline $\mathrm{T} 1212$ & 12 & 12 & 1.00 \\
\hline $\mathrm{T} 1214$ & 12 & 16 & 1.17 \\
\hline $\mathrm{T} 1216$ & 12 & 18 & 1.33 \\
\hline $\mathrm{T} 1218$ & 12 & 20 & 1.50 \\
\hline $\mathrm{T} 1220$ & 12 & 16 & 1.67 \\
\hline $\mathrm{T} 1616$ & 16 & 20 & 1.00 \\
\hline $\mathrm{T} 1618$ & 16 & 21.3 & 1.13 \\
\hline $\mathrm{T} 1620$ & 16 & 24 & 1.25 \\
\hline $\mathrm{T} 1621$ & 16 & & 1.50 \\
\hline $\mathrm{T} 1624$ & 16 & \\
\hline
\end{tabular}

これらの式から求めた応力増加係数を, 主桁ウェブの 公称応力あるいは横桁下フランジの公称応力に乗じるこ とで，2軸応力下での疲労寿命を評価できるとした.

しかし，上記の研究で用いたのは図-2に示寸試験体 1 種類であり, 疲労強度や応力増加係数に対する板厚や溶 接形状（脚長，止端曲率半径）の影響は考慮されていな い. 2軸応力の影響を考慮した交差部の疲労寿命評価方 法を確立する上で，これらの影響を明らかにすることが 不可欠である. 本研究では, 応力増加係数に対する板厚, 溶接形状の影響を解析的に明らか寸る。 そして, 疲労試 験により板厚と溶接形状が疲労強度に及ぼす影響につい て実験的に検討する．これらの結果に基づき，2軸応力 下にある交差部の疲労強度・寿命評価法を提案する.

\section{2. 応力増加係数の解析}

\section{(1) 解析対象および方法}

応力増加係数に対する板厚と溶接形状の影響を明らか にする目的で3次元有限要素応力解析を行った. 解析対 象の概形はこれまでの研究で用いてきたモデル試験体と 同じである. 本解析でパラメータとしたのは, 疲労強度 に対する影響が大きいと考えられる，板厚，溶接脚長， 止端曲率半径, 横桁フランジコーナ一部の面取り半径で ある. 止端曲率半径と面取り半径の定義を図-3に示す。

解析モデルは，以下の3シリーズからなっている. シ リーズIは，板厚をパラメータとしたものである．表-1 に示寸ように，主桁ウェブ厚は9〜16mm, 横椼フランジ 厚は9〜24mmとしている，これらの板厚は，支間20〜 
表-2 解析モデル (シリーズ II)

\begin{tabular}{|c|c|c|c|}
\hline $\begin{array}{c}\text { モデル } \\
\text { 名称 }\end{array}$ & $\begin{array}{c}\text { 主桁ウェブ側 } H_{w} \\
(\mathrm{~mm})\end{array}$ & $\begin{array}{c}\text { 横桁フランジ側 } H_{f} \\
(\mathrm{~mm})\end{array}$ & $\begin{array}{c}\text { 脚長比 } \\
H_{f} / H_{w}\end{array}$ \\
\hline H0606 & 6 & 6 & 1.00 \\
\hline H0609 & 6 & 9 & 1.50 \\
\hline H0612 & 6 & 12 & 2.00 \\
\hline H0906 & 9 & 6 & 0.67 \\
\hline H0909 & 9 & 9 & 1.00 \\
\hline H0923 & 9 & 12 & 1.33 \\
\hline H1206 & 12 & 6 & 0.50 \\
\hline H1209 & 12 & 9 & 0.75 \\
\hline H1212 & 12 & 12 & 1.00 \\
\hline
\end{tabular}

表-3 解析モデル (シリーズ III)

\begin{tabular}{|c|c|c|}
\hline $\begin{array}{c}\text { モデル } \\
\text { 名称 }\end{array}$ & $\begin{array}{c}\text { 溶接部止端半径 } R \\
(\mathrm{~mm})\end{array}$ & $\begin{array}{c}\text { 面取り半径 } r \\
(\mathrm{~mm})\end{array}$ \\
\hline $\mathrm{R} 0100$ & 1 & 0 \\
\hline $\mathrm{R} 0101$ & 1 & 1 \\
\hline $\mathrm{R} 0102$ & 1 & 2 \\
\hline $\mathrm{R} 0103$ & 1 & 3 \\
\hline $\mathrm{R} 0301$ & 3 & 1 \\
\hline $\mathrm{R} 0601$ & 6 & 1 \\
\hline $\mathrm{R} 1000$ & 10 & 0 \\
\hline $\mathrm{R} 1001$ & 10 & 1 \\
\hline $\mathrm{R} 1002$ & 10 & 2 \\
\hline $\mathrm{R} 1003$ & 10 & 3 \\
\hline $\mathrm{R} 2001$ & 20 & 1 \\
\hline $\mathrm{R} 4001$ & 40 & 1 \\
\hline
\end{tabular}

60mの4主林I断面橋梁の試設計結果を基に設定した．溶 接部は脚長 $6 \mathrm{~mm}$ 等脚でその止端曲率半径は $1 \mathrm{~mm}$ として いる. また，横桁フランジコーナ一部の面取り半径は $1 \mathrm{~mm}$ とした.

シリーズா溶接脚長をパラメータとしたモデルである 表-2にシリーズПの各モデルの溶接脚長を示す．溶接脚 長は，主桁ウェブ側，横桁フランジ側とも6〜12mmとし ている. これらは道路橋示方書5)のすみ肉溶接サイズの 規定を満たすように設定した。溶接止端の曲率半径は $1 \mathrm{~mm}$ とている。主桁ウェブ厚は $12 \mathrm{~mm}$ ，横桁フランジ 厚は16mmとし, 横桁フランジコーナ一部の面取り半径 は1mmとしている.

シリーズIIIは, 溶接止端の曲率半径と横桁フランジコ 一ナ一部の面取り半径をパラメータとしたモデルである。 各モデルの止端曲率半径とコーナ一部面取り半径を表-3 に示す. 止端曲率半径は1〜 40mmとしている. 止端曲率 半径 $1 \mathrm{~mm}$ は溶接ままの仕上げ，3mmは止端仕上げ， $6 \mathrm{~mm}$ はR仕上げ，さらに大きい場合はフィレット仕上げに相 当する. 面取り半径は0〜3mmとした．板コーナ一部の 塗膜厚を確保する目的で，コーナ一部には曲率 $1 \mathrm{~mm}$ 以上 の面取りが施される.さらに2mmあるいは3mmとすれば, コーナ一部の塗膜厚が確保しやすいとされている. 主桁

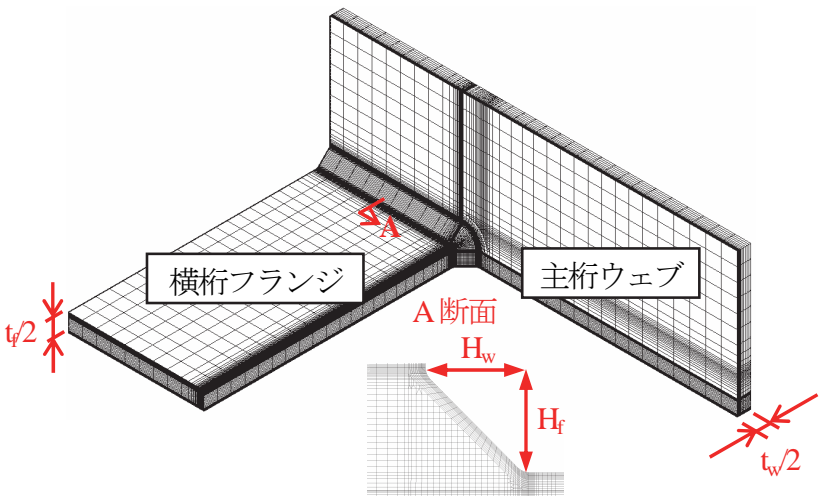

図-4 要素分割図

ウェブ厚は12mm, 横桁フランジ厚は16mm, 溶接部は脚 長 $6 \mathrm{~mm}$ 等脚の三角形断面としている.

各パラメータが応力集中係数に及ぼす影響を検討する ために，主桁ウェブ厚を $12 \mathrm{~mm}$ ，横林フランジ厚を $16 \mathrm{~mm}$, 主桁ウェブ側溶接脚長および横林フランジ側溶接脚長を $6 \mathrm{~mm}$, 止端曲率半径を $1 \mathrm{~mm}$, 面取り半径を $1 \mathrm{~mm}$ とたた デルを基準とした. 以後，これを基準モデルと呼ぶ.

解析は試験体の対称性を考慮して1/8モデルで行った. 使用した解析コードはCAFEMである，要素分割は8節点 固体要素を用いて行った。着目する主桁ウェブ側止端部 および横桁フランジ側止端部の要素寸法は0.05mmであ る. 鋼材のヤング率は $2.0 \times 10^{5} \mathrm{~N} / \mathrm{mm}^{2}$ ，ポアソン比は0.3 とした。要素分割図の例を図-4に示す.

主桁ウェブ端部および横桁フランジ端部に等分布荷重 を作用させて解析を行った。荷重条件は，主桁ウェブの 公称応力を $100 \mathrm{~N} / \mathrm{mm}^{2}$ とし状態で横桁フランジの公称 応力を-100, $0,100 \mathrm{~N} / \mathrm{mm}^{2}$ としたケースと, 横桁フラン ジの公称応力を $100 \mathrm{~N} / \mathrm{mm}^{2}$ とした状態で主桁ウェブの公 称応力を-100，0，100N/mm²としたケースとした.

\section{(2) 応力性状}

解析より求めた基準モデルの交差部まわし溶接部近傍 の最大主応力のコンター図を図-5に示す. 図-5(a) は, 主桁ウェブのみに公称応力 $100 \mathrm{~N} / \mathrm{mm}^{2}$ を載荷した場合の 主応力コンターである. 最大主応力はまわし溶接部中央 の主桁ウェブ側止端部で最大 $\left(394 \mathrm{~N} / \mathrm{mm}^{2}\right)$ となってい る.また，主桁ウェブ側に載荷しているにも関わらず, 横桁フランジ側止端には約 $200 \mathrm{~N} / \mathrm{mm}^{2}$ の応力が生じてお り，主桁ウェブからまわし溶接部を介して横桁フランジ へ応力が伝達されている.

図-5(b) は横桁フランジのみに公称応力 $100 \mathrm{~N} / \mathrm{mm}^{2}$ を載 荷した時の主応力コンター図である. 横桁フランジのコ 一ナ一部で $356 \mathrm{~N} / \mathrm{mm}^{2}$ の主応力が生じているのに対し, 主桁ウェブ側止端部の主応力は $50 \mathrm{~N} / \mathrm{mm}^{2}$ 程度と, 比較的 小さい. 


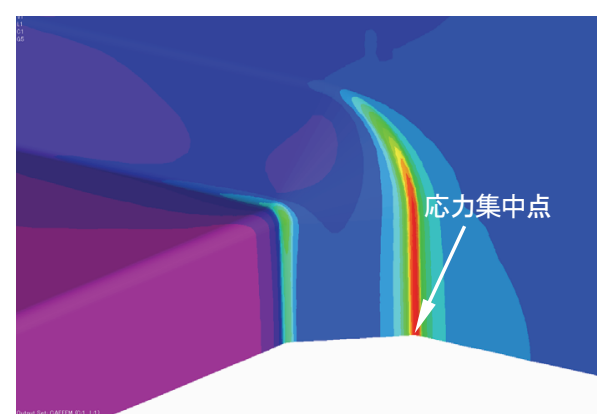

(a) 主林ウェブのみ載荷

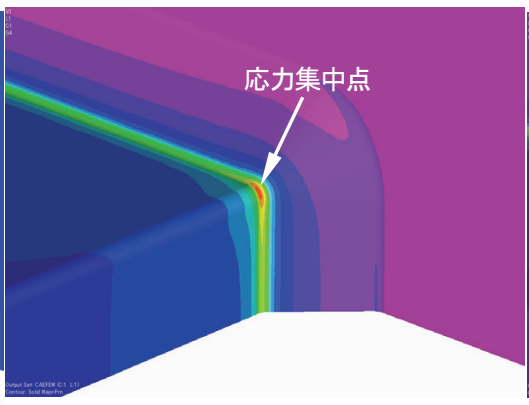

(b) 横桁フランジのみ載荷

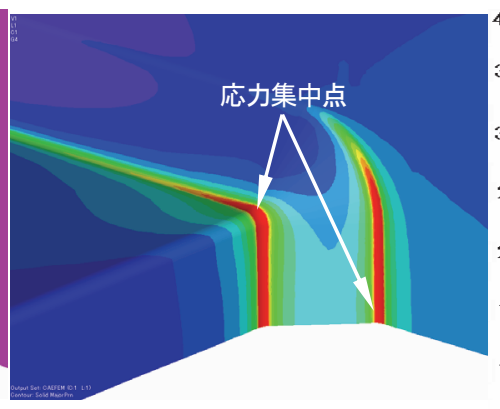

(c) 2 軸載荷

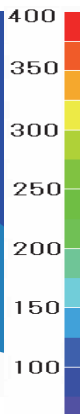

50

図-5＼cjkstart溶接部近傍の主応カコンター（基準モデル）

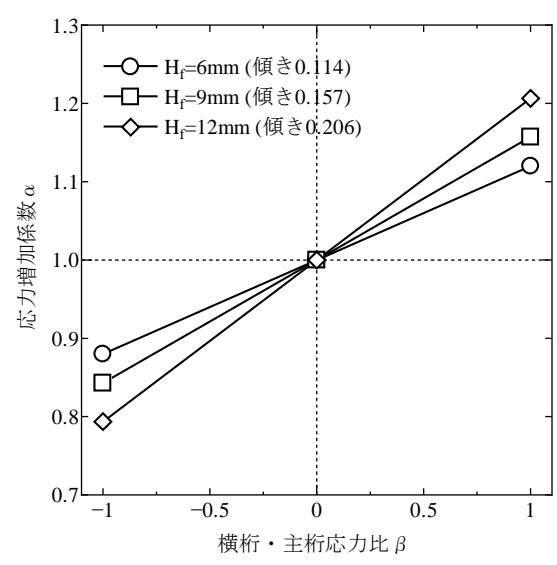

(a) 主林ウェブ側脚長 $H_{w}=6 \mathrm{~mm}$

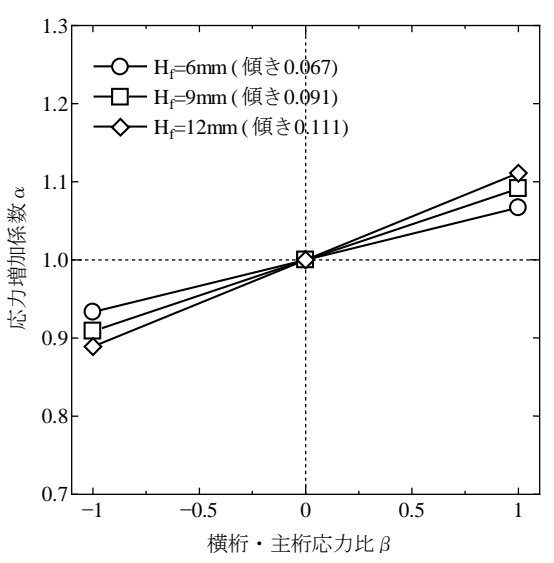

(b) 主林ウェブ側脚長 $H_{w}=9 \mathrm{~mm}$

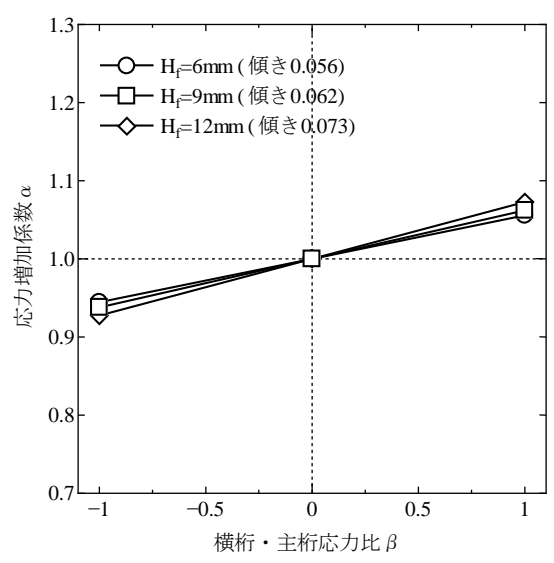

（c）主桁ウェブ側脚長 $H_{w}=12 \mathrm{~mm}$

図-6 応力増加係数と横林 ・主林応力比の関係（主桁側止端部）

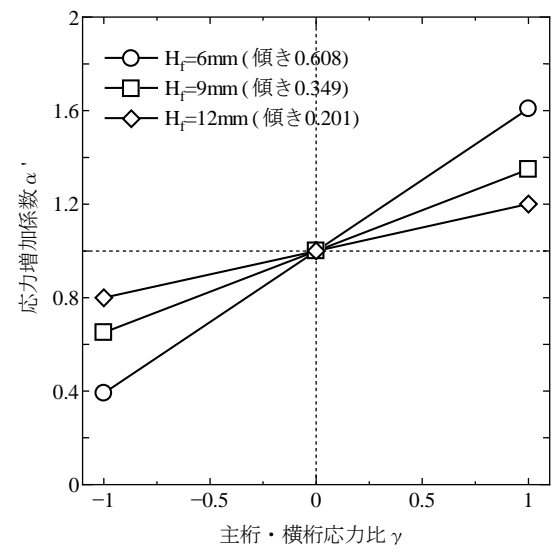

(a) 主林ウェブ側脚長 $H_{w}=6 \mathrm{~mm}$

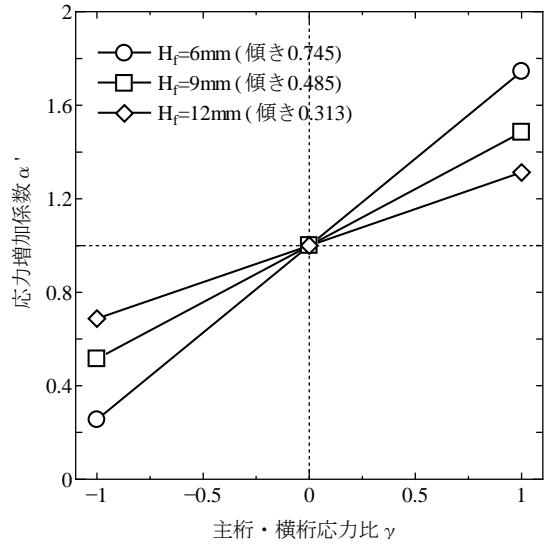

(b) 主林ウェブ側脚長 $H_{w}=9 \mathrm{~mm}$

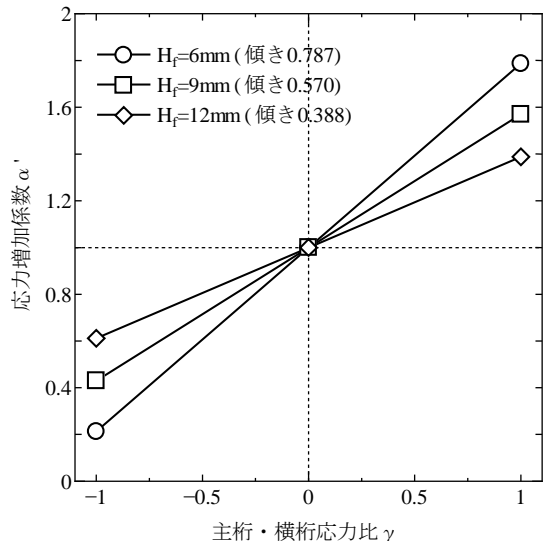

（c）主桁ウェブ側脚長 $H_{w}=12 \mathrm{~mm}$

図-7 応力増加係数と主桁・横林応力比の関係（横桁フランジコーナ一部）

図-5(c) は主桁ウェブ，横桁フランジの両方に公称応 力 $100 \mathrm{~N} / \mathrm{mm}^{2}$ を載荷した時の主応力コンター図である. 2 軸応力作用時は上記 $2 つ の 1$ 軸応力状態の重ね合わせとな るため，主桁ウェブ側止端部，横林フランジコーナー部 の両方で応力集中が生じている. 主応力の值は, 主桁ウ ェブ側止端部で $441 \mathrm{~N} / \mathrm{mm}^{2}$, 横桁フランジコーナー部で 573N/mm²となり, 横析フランジコーナー部の方が大き くなっている.

\section{(3) 応力増加係数}

すべての解析モデルに対して，主桁ウェブ側止端部お よび横桁フランジコーナ一部の応力増加係数と横桁・主 桁応力比, 主桁・横桁応力比の関係を調べた. 溶接脚長 を変化させた場合（シリーズI）を例として，主桁ウェ ブ側止端部の応力増加係数 $\alpha$ と横桁・主桁応力比 $\beta$ の関係 を図-6に，横桁フランジコーナ一部の応力増加係数 $\alpha^{\prime}$ と 主桁・横桁応力比 $\gamma$ 関係を図-7に示寸. 


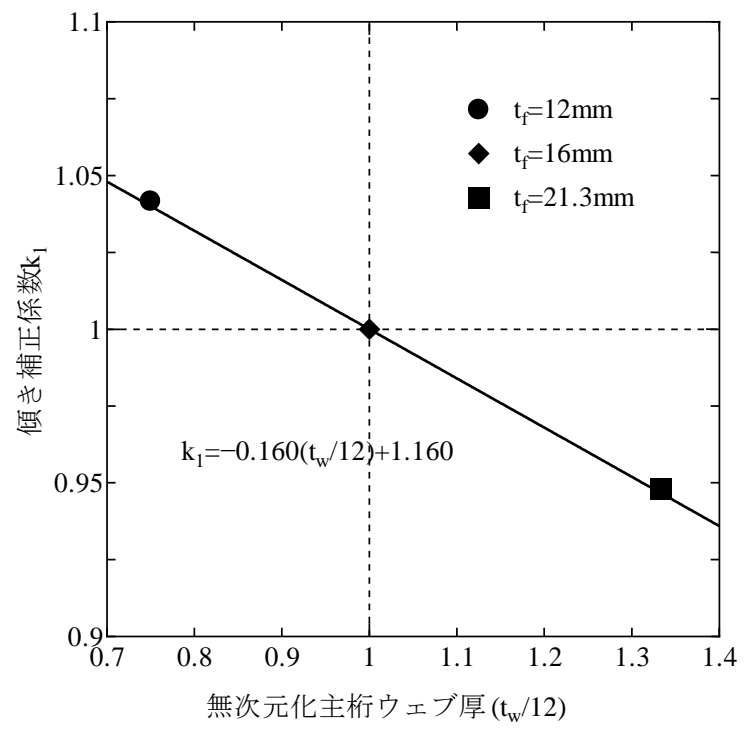

図-8＼cjkstart傾き補正係数と主桁ウェブ厚の関係

応力増加係数と横桁 ・ 主桁応力比あるいは主桁 ・横桁 応力比は，いずれの場合にも，線形関係にある。これは， 前項で述べたように，重㸚わせ則が成り立つことによ る. ただし，モデルによって線形関係の傾きが異なって いる. 主桁ウェブ側止端部では, 横桁・主桁応力比 1.0 の時の応力は 1 軸応力状態（横桁・主析応力比0）に比心゙ て5〜20\%増加しているのに対し，横林フランジコーナ 一部の場合には20～80\%増加している. この応力の変化 を疲労強度の変化として考えると，主桁ウェブ側止端部 では，2軸応力状態（横桁・主桁応力比 $=1.0 ）$ となって も，疲労強度の低下は20\%程度以下にすぎないことにな る. これは，日本鋼構造協会の「鋼構造物の疲労設計指 針・同解説」の（以下，JSSC指針）で定められいる疲労 強度等級1ランク以下の疲労強度の変化に対応する.こ れに対して，横桁フランジコーナ一部では疲労強度等級 が1〜3ランク変化することになる. シリーズIとシリー ズШにおいても, 応力増加係数と横桁・主桁応力比, 主 桁・横桁応力比の関係を求めたが，主桁ウェブ側溶接止 端と横桁フランジコーナ一部の主応力の変化は, シリー ズாと同じ傾向であった.

以上のことから，主桁ウェブ側止端部では2軸応力の 影響を考慮する必要はない，また横桁フランジコーナー 部は比較的大きな疲労強度の変化を伴うため, 2軸応力 の影響を考慮する必要があると考えられる，そのため， 以後の検討では, 横桁フランジコーナ一部に注目する.

すべての解析モデルについて, 横桁フランジコーナー 部の応力増加係数 $\alpha$ 'と主桁・横析応力比 $\gamma$ 関係から直 線の傾きを求めた．この傾きは， $\gamma=1$ （主桁ウェブに作 用寸る公称応力が，横桁フランジに作用寸る公称応力と 同じ大きさ）となったときの主応力の増加率に相当する。 シリーズIのモデル（板厚をパラメータ）での傾きは

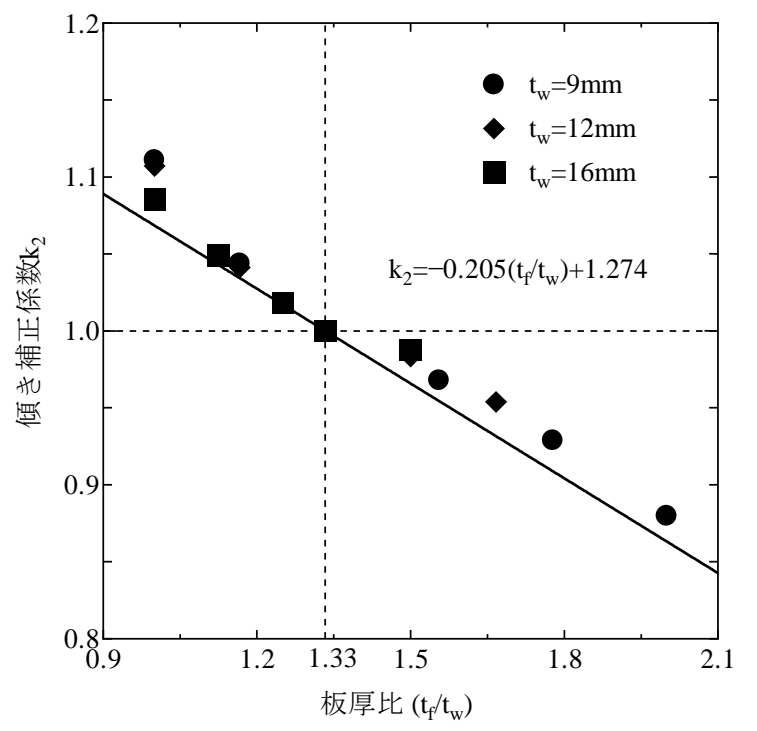

図-9 傾き補正係数と板厚比の関係

0.557〜 0.704の範囲にあり, 傾きの最大值と最小值の比 は1.26となっている. シリーズII（溶接脚長をパラメー タ）での傾きは $0.201 〜 0.787$ 範囲にあり, 最大值と最 小值の比は3.92である. 同様に，シリーズயIIの止端曲率 半径をパラメータとした場合の傾きは $0.395 \sim 0.587$ の範 囲にあり, 最大值と最小值の比は1.49, 面取り半径をパ ラメータとした場合の最大值と最小值の比は1.04であっ た. 傾きの最大值と最小值の比は，そのパラメータによ って応力増加係数がどの程度変化するかを示すものであ る. 例えば, 面取り半径を 0 ３mmと変えても, 応力増 加係数の変化は $4 \%$ 以下，すなわち横桁フランジの公称 応力で疲労寿命を整理する場合の疲労強度の低下は $4 \%$ 以下となる. したがって, 面取り半径が応力増加係数に 及ぼす影響を考慮する必要はないと考えられる。また， 板厚, 溶接脚長, 止端半径をパラメータとした場合の傾 きの最大值と最小值の比は1.20を超えるため, その影響 を無視することはできないと判断する.

\section{(4) 応力増加係数の算定式}

疲労設計において 2 軸応力の影響を考慮するには, 様々な形状を有寸る交差部の応力増加係数を求める必要 がある．実際の設計作業を考えれば，任意の交差部構造 の応力増加係数は, 基準モデルの応力増加係数に各影響 因子の補正係数を乗じて求めることが実用的と考える. 考慮する因子としては, 先に示したように, 板厚, 溶接 脚長, 止端半径である. なお，ここでは，基準モデルの 傾きに対する各モデルの傾きの比を傾き補正係数 $k$ と定 義する.

図-8〜図-12 に傾き補正係数と各因子の関係を示す. 図中の式は, 解析から得られた值に最小二乗法を適用し て求めた各因子に対寸る補正係数の算出式である. 


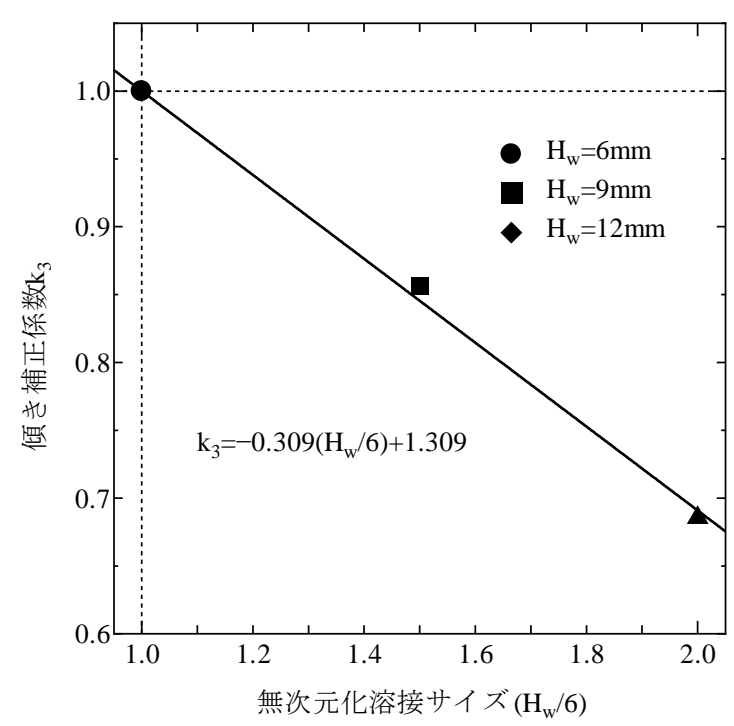

図-10 傾き補正係数との主桁ウェブ側溶接脚長の関係

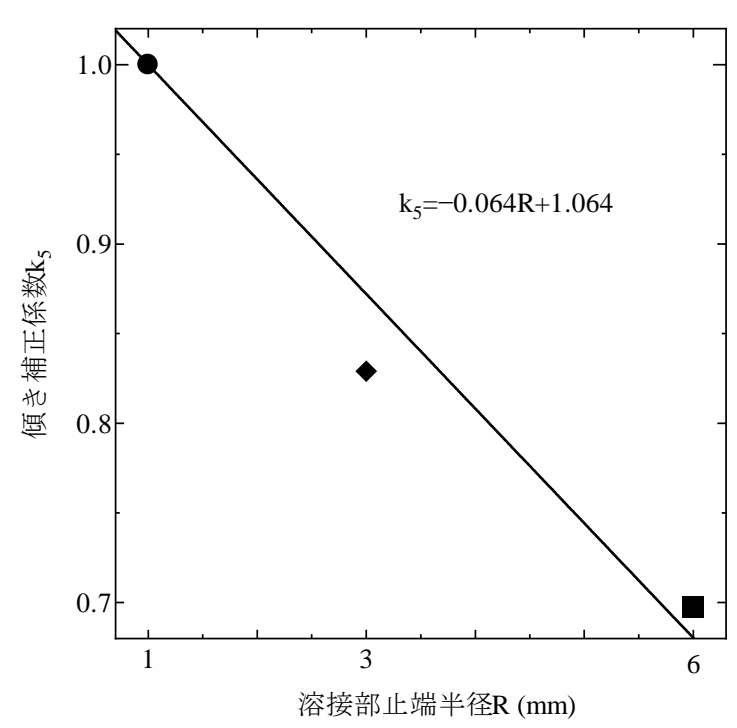

図-12 傾き補正係数と溶接部止端半径の関係

次式に示寸通り, 算出式から求めた補正係数を基準乇 デルの傾きに乗じることで，任意の板厚，溶接形状およ び止端半径を有するモデルの傾きを求めることができる.

$$
a=k_{1} \cdot k_{2} \cdot k_{3} \cdot k_{4} \cdot k_{5} \cdot a_{0}
$$

$a_{0}:$ 基準モデルの傾き $(0.608)$

$$
\begin{array}{ll}
k_{1}=-0.160\left(t_{w} / 12\right)+1.160 & 9 \leqq t_{w} \leqq 21 \mathrm{~mm} \\
& \left(t_{w}: \text { 主桁ウェブの板厚 }\right) \\
k_{2}=-0.205\left(t_{f} / t_{w}\right)+1.274 & 1 \leqq t_{f} / t_{w} \leqq 2 \\
& \left(t_{f}: \text { 横桁フランジの板厚 }\right) \\
k_{3}=-0.309\left(H_{w} / 6\right)+1.309 & 6 \leqq H_{w} \leqq 12 \mathrm{~mm}
\end{array}
$$$$
k_{4}=-0.563\left(H_{f} / H_{w}\right)^{3}+2.904\left(H_{f} / H_{w}\right)^{2}
$$$$
\left(H_{w}:\right. \text { 主林ウェブ側の脚長) }
$$$$
-5.417\left(H_{f} / H_{w}\right)+4.076 \quad 0.5 \leqq H_{f} / H_{w} \leqq 2.0
$$$$
\left(H_{f}: \text { 横林フランジ側の脚長 }\right)
$$

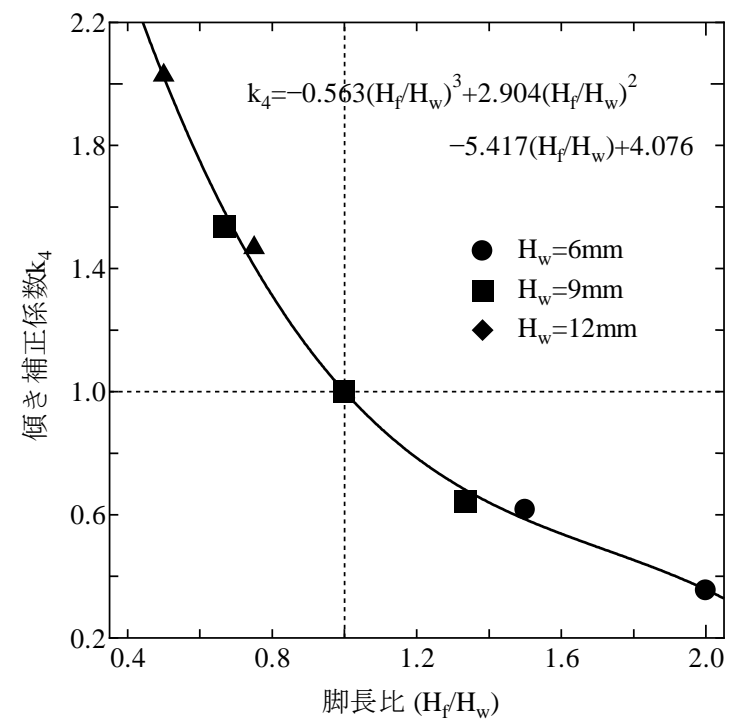

図-11 傾き補正係数と脚長比の関係

表-4 任意形状の解析モデル

\begin{tabular}{|c|c|c|c|c|c|}
\hline$H_{w}(\mathrm{~mm})$ & $H_{f}(\mathrm{~mm})$ & $H_{f} / H_{w}$ & $t_{w}(\mathrm{~mm})$ & $t_{f}(\mathrm{~mm})$ & $t_{f} / t_{w}$ \\
\hline 8 & 6 & 0.75 & 12 & 14 & 1.17 \\
\hline 10 & 12 & 1.20 & 14 & 21 & 1.50 \\
\hline 8 & 10 & 1.25 & 10 & 15 & 1.50 \\
\hline 7 & 12 & 1.71 & 12 & 20 & 1.67 \\
\hline
\end{tabular}

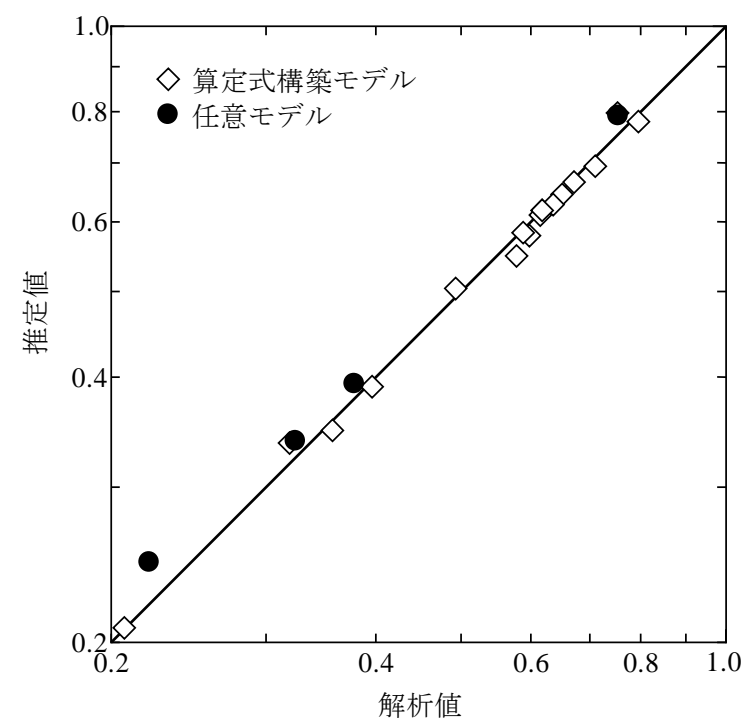

図-13 推定值と解析值の比較

$$
k_{5}=-0.064 R+1.064 \quad 1 \leqq R \leqq 6 \mathrm{~mm}
$$

$(R:$ 溶接止端の曲率半径)

図-13 に応力解析から求めた傾きと式(3)加求めた傾 きを比較した結果を示寸．図中には，表-4 に示寸傾き 算定式に用いた以外のモデルに対する結果も示している. 両者はほぼ一致していることから，ここで用いたパラメ 一タの範囲内であれば式(3)により任意の形状・寸法を 有する交差部構造の横林フランジコーナー部の応力増加 
表-5 SM490YAの機械的性質と化学成分

(a) 機械的性質

\begin{tabular}{|c|c|c|c|}
\hline 板厚 & 降伏点 & 引張強さ & 伸び \\
\hline $9 \mathrm{~mm}$ & $420 \mathrm{~N} / \mathrm{mm}^{2}$ & $550 \mathrm{~N} / \mathrm{mm}^{2}$ & $27 \%$ \\
\hline $16 \mathrm{~mm}$ & $430 \mathrm{~N} / \mathrm{mm}^{2}$ & $561 \mathrm{~N} / \mathrm{mm}^{2}$ & $22 \%$ \\
\hline
\end{tabular}

(b) 化学成分

\begin{tabular}{|c|c|c|c|c|c|c|c|}
\hline 板厚 & $\mathrm{C}$ & $\mathrm{Si}$ & $\mathrm{Mn}$ & $\mathrm{P}$ & $\mathrm{S}$ & $\mathrm{Cu}$ & $\mathrm{Ni}$ \\
\hline $9 \mathrm{~mm}$ & 0.16 & 0.24 & 1.43 & 0.012 & 0.003 & 0.01 & 0.01 \\
\hline $16 \mathrm{~mm}$ & 0.16 & 0.24 & 1.46 & 0.010 & 0.003 & 0.01 & 0.02 \\
\hline
\end{tabular}

係数と主桁・横桁応力比の関係の傾きをある程度精度よ く求めることができるといえる.

以上より, 横林フランジコーナ一部の応力増加係数 $\alpha$, と主桁・横桁応力比 $\gamma$ の関係は, 式(3)のaを利用して式(4) で与えられることになる.

$$
\alpha=a \cdot \gamma+1
$$

\section{3. 疲労試験}

\section{(1) 試験体}

前章で示した応力増加係数の算定式の適用性を確認す る目的で，疲労試験を行った。試験体は，その概形が文 献2)〜4)で用いた十字試験体（図-2参照）と同じ，主桁

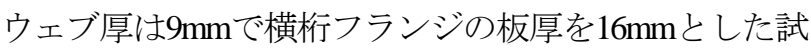
験体（T試験体）と，主桁ウェブ厚および横桁フランジ 厚は9mmで溶接形状を等脚とした試験体（L試験体）か らなっている．使用鋼材はSM490YAである．鋼材の機 械的性質と化学成分を表-5に示す.

試験体は以下の手順で製作した．鋼板から主桁ウェブ を想定した板 $(120 \mathrm{~mm} \times 700 \mathrm{~mm})$ と横桁フランジを想定 した板 $(120 \mathrm{~mm} \times 700 \mathrm{~mm})$ を切り出し， ウェブ中央にフ ランジを差し込むためのスリット（（板幅+2mm） X (板厚+2mm））を設ける.このスリットに横桁フラン ジを想定した板を差し込み，主桁ウェブ片面と横桁フラ ンジを組立て溶接した後, 主桁ウェブ表面からウェブ板 厚の $2 / 3$ 程度までガウジングし，そこに2層の溶接を施 す. その後, ウェブ裏面にも同様のガウジングと溶接を 施すことにより完全溶け込み溶接とした．溶接は水平姿 勢の $\mathrm{CO}_{2}$ 溶接で行った. 使用した溶接材料は径 $1.2 \mathrm{~mm} の$ フラックス入りワイヤ，溶接時の電流は230A，電圧は $32 \mathrm{~V}$, 速度は 26cm/minである.

溶接ままの試験体では，横桁フランジ側止端部に降伏 点に近い圧縮の残留応力が発生する2)が，実際の構造物 では部材の拘束により横桁フランジ側止端部に圧縮残留 応力が発生しているかどうかは不明である，そのため， L試験体の一部については, 残留応力除去焼鈍を施した.
表-6 溶接形状の測定結果

\begin{tabular}{|c|c|c|c|c|}
\hline & & & T試験体 & $\mathrm{L}$ L試験体 \\
\hline \multirow{2}{*}{ 主 } & \multirow{2}{*}{$\begin{array}{l}\text { 脚長 } \\
(\mathrm{mm})\end{array}$} & 平均值 & 15.4 & 8.2 \\
\hline & & 標準偏差 & 1.1 & 0.7 \\
\hline \multirow{2}{*}{$\begin{array}{l}\text { ウ } \\
\text { ウ }\end{array}$} & \multirow{2}{*}{$\begin{array}{c}\text { 曲率半径 } \\
(\mathrm{mm})\end{array}$} & 平均值 & 1.0 & 3.1 \\
\hline & & 標準偏差 & 0.6 & 1.7 \\
\hline \multirow{2}{*}{$\begin{array}{l}\text { ブ } \\
\text { 側 }\end{array}$} & \multirow{2}{*}{$\begin{array}{l}\text { 開き角 } \\
\text { (度) }\end{array}$} & 平均值 & 129.0 & 148.0 \\
\hline & & 標準偏差 & 6.0 & 7.0 \\
\hline \multirow{6}{*}{$\begin{array}{l}\text { 横 } \\
\text { 桁 } \\
\text { ᄀ } \\
\text { ラ } \\
\text { Z } \\
\text { 側 }\end{array}$} & \multirow{2}{*}{$\begin{array}{l}\text { 脚長 } \\
(\mathrm{mm})\end{array}$} & 平均值 & 8.3 & 8.5 \\
\hline & & 標準偏差 & 0.7 & 0.9 \\
\hline & \multirow{2}{*}{$\begin{array}{c}\text { 曲率半径 } \\
(\mathrm{mm})\end{array}$} & 平均值 & 2.9 & 5.6 \\
\hline & & 標準偏差 & 0.7 & 2.0 \\
\hline & \multirow{2}{*}{$\begin{array}{l}\text { 開き角 } \\
\text { (度) }\end{array}$} & 平均値 & 128.0 & 149.0 \\
\hline & & 標準偏差 & 7.0 & 5.0 \\
\hline
\end{tabular}

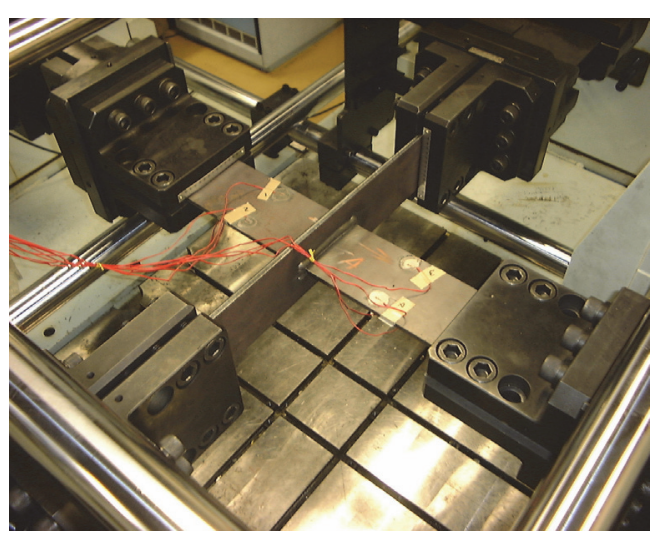

図-14 疲労試験状況

焼鈍は，昇温速度 $220^{\circ} \mathrm{C} / \mathrm{h}$ で $625^{\circ} \mathrm{C}$ ま゙加熱して約 1 時間保 持した後, 降温速度 $280^{\circ} \mathrm{C} / \mathrm{h}$ で $280^{\circ} \mathrm{C}$ となった時に炉から 取り出し空冷することにより行った. 以後, 溶接ままの L試験体をLA試験体，後熱処理を施した試験体をLP試験 体と呼ぶ.

全ての試験体について，試験実施前にまわし溶接部の 溶接脚長，止端半径，開き角を測定した．測定は，歯科 用印象材で溶接部の型を取った後，採取した型を厚さ 2.0mmにスライスし，それらを20倍の拡大投影機で観察 することで行った，サンプル数は，T試験体で64， L試 験体で80である．測定結果を表-6に示す。

\section{(2) 疲労試験方法}

疲労試験は，動的能力 $200 \mathrm{kN}$ の2軸疲労試験装置を利 用して，試験体の主桁ウェブと横桁フランジに同位相の 繰返し引張荷重（下限荷重 : 5kN) 下で行った. 試験状 況を図-14に示す. 文献2）での検討結果から，2軸繰返 し荷重時の繰返し速度は1.5Hz，1軸繰返し荷重時の繰返 し速度は5Hzとした。

主桁ウェブ側止端部を対象とする場合，T試験体では， 主桁ウェブの応力範囲を $100 \mathrm{~N} / \mathrm{mm}^{2}$ で一定として，横桁 フランジの応力範囲を $0,25,50,75 \mathrm{~N} / \mathrm{mm}^{2}, \mathrm{LA}$ 試験体 では主桁ウェブの応力範囲を $100 \mathrm{~N} / \mathrm{mm}^{2}$ で一定として, 横林フランジの応力範囲を $0,50,100 \mathrm{~N} / \mathrm{mm}^{2}$ とした. 


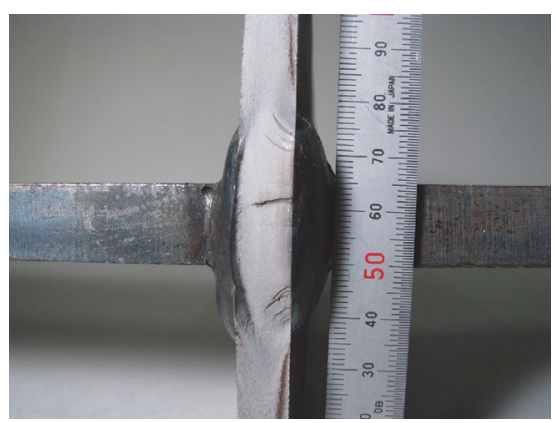

(a) Tシリーズ $\left(\Delta \sigma_{w}=100 \mathrm{~N} / \mathrm{mm}^{2}, \Delta \sigma_{f}=75 \mathrm{~N} / \mathrm{mm}^{2}\right)$

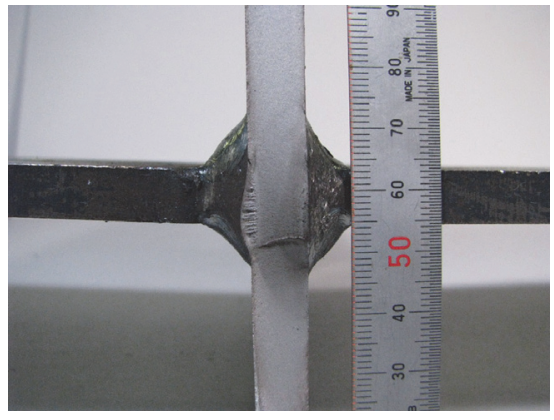

(b) L シリーズ $\left(\Delta \sigma_{w}=\Delta \sigma_{f}=100 \mathrm{~N} / \mathrm{mm}^{2}\right)$

図-15＼cjkstart溶接まま試験体の疲労破面

交差部においては，主桁ウェブ側止端部と横桁フラン ジ側止端部の2箇所が疲労き裂の発生起点になると想定 される．横桁フランジ側止端での疲労破壊を想定した疲 労試験にはLP試験体を用いた。その際，横林フランジ の応力範囲は $150 \mathrm{~N} / \mathrm{mm}^{2}$ で一定として, 主桁ウェブの応 力範囲を $0,50,100 \mathrm{~N} / \mathrm{mm}^{2}$ とした.

\section{(3) 主桁ウェブ側止端破壊を想定した疲労試験結果}

$\mathrm{T}$ 試験体とLA試験体の疲労破面を図-15に示す。これ までの疲労試験と同様に，全ての試験体において，疲労 き裂は主桁ウェブ側止端部から発生し，進展・破断に至 った.

T試験体およびLA試験体の疲労試験結果を表-7に示す。 また，図-16には疲労寿命と横桁・主桁応力比（横桁フ ランジ応力範囲／主桁ウェブ応力範囲）の関係を示して いる. 図中には，比較のために文献2）の結果（板厚： $9 \mathrm{~mm}$, 主桁ウェブ側の脚長 : $11.9 \mathrm{~mm}$, 横桁フランジ側 の脚長 : $8.2 \mathrm{~mm}$ ) も示している. 横桁フランジ厚を $16 \mathrm{~mm}$ としたT試験体の場合, 横林・主林応力比0（1軸応 力状態）では3体中2体が1000万回まで載荷しても未破断 であるのに対し，2軸応力状態（横桁・主桁応力比 0.25 〜0.75）となることで疲労寿命は100万回前後となってい る.ただし，2軸応力状態であっても，横桁・主桁応力 比によって疲労寿命に明確な差は認められない.

溶接脚長を等脚としたLA試験体の場合，横桁・主桁 応力比 0 と0.5では疲労寿命はほぼ同じ，横桁・主林応力 表-7＼cjkstart疲労試験結果（溶接まま試験体）

\begin{tabular}{|c|c|c|c|}
\hline & $\begin{array}{c}\text { 主桁ウェブ } \\
\text { 応力範囲 } \\
\left(\mathrm{N} / \mathrm{mm}^{2}\right)\end{array}$ & $\begin{array}{c}\text { 横桁フランジ } \\
\text { 応力範囲 } \\
\left(\mathrm{N} / \mathrm{mm}^{2}\right)\end{array}$ & $\begin{array}{c}\text { 疲労寿命 } \\
\text { (万回) }\end{array}$ \\
\hline \multirow{10}{*}{ Tシリーズ } & 100 & 0 & 未破断 \\
\hline & 100 & 0 & 未破断 \\
\hline & 100 & 0 & 338.0 \\
\hline & 100 & 25 & 116.3 \\
\hline & 100 & 25 & 82.6 \\
\hline & 100 & 50 & 160.2 \\
\hline & 100 & 50 & 72.5 \\
\hline & 100 & 50 & 132.6 \\
\hline & 100 & 75 & 65.3 \\
\hline & 100 & 75 & 113.9 \\
\hline \multirow{5}{*}{ Lシリーズ } & 100 & 0 & 152.1 \\
\hline & 100 & 0 & 200.0 \\
\hline & 100 & 50 & 150.5 \\
\hline & 100 & 50 & 203.6 \\
\hline & 100 & 100 & 88.0 \\
\hline
\end{tabular}

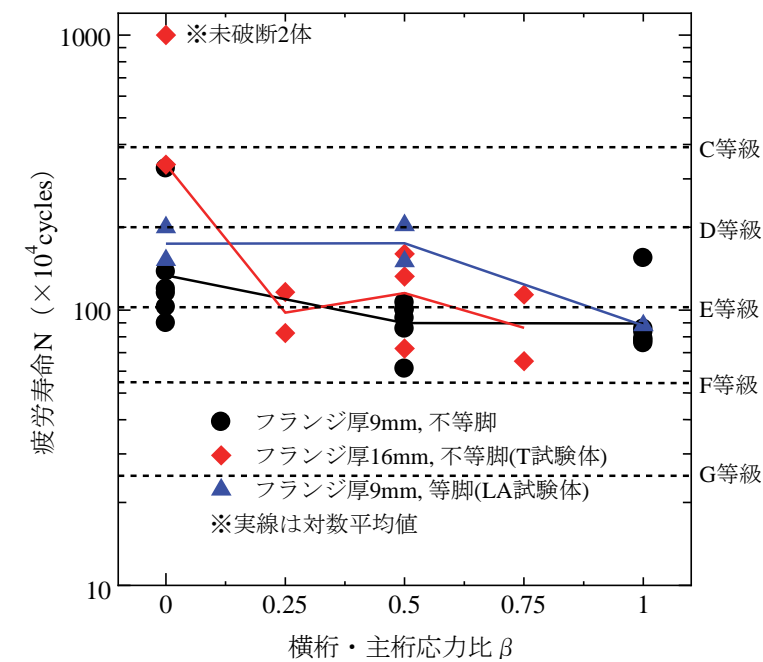

図-16 疲労寿命一横桁・主桁応力比関係

比1.0で半減しており，2軸応力の影響は明確ではない.

図-16中の横に引いた点線は，JSSC指針で示されてい る各疲労強度等級の応力範囲 $100 \mathrm{~N} / \mathrm{mm}^{2}$ に対する疲労寿 命を示している. JSSC指針では，交差部の主桁ウェブ 側止端部は面外ガセット溶接継手にモデル化し，疲労強 度等級を $\mathrm{G}$ 等級としている. 疲労試験結果はすべてF等 級以上であり，かつ2軸応力による疲労寿命の著しい減 少は認められない。したがって，主桁ウェブ側止端部に ついては，疲労寿命を評価するにあたり，2軸荷重の影 響を考慮する必要はないと判断される.

\section{（4）横桁フランジ側止端破壊を想定した疲労試験結果} 熱処理したLP試験体の疲労破面の例を図-17に示す. $\Delta \sigma_{w}($ 主桁ウェブの公称応力範囲 $)=0, \Delta \sigma_{f}$ (横桁フラン ジの公称応力範囲 $)=150 \mathrm{~N} / \mathrm{mm}^{2}$ ，および $\Delta \sigma_{w}=50 \mathrm{~N} / \mathrm{mm}^{2}$, 


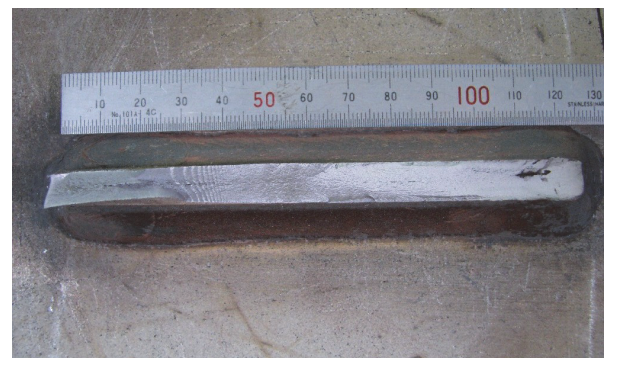

(a) $\Delta \sigma_{w}=50 \mathrm{~N} / \mathrm{mm}^{2}, \Delta \sigma_{f}=150 \mathrm{~N} / \mathrm{mm}^{2}$

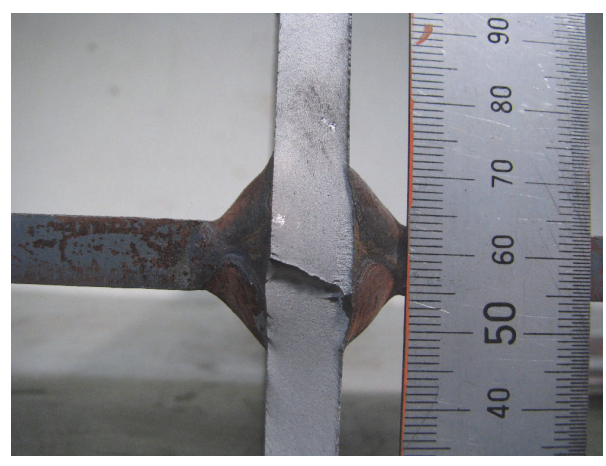

(b) $\Delta \sigma_{w}=100 \mathrm{~N} / \mathrm{mm}^{2}, \Delta \sigma_{f}=150 \mathrm{~N} / \mathrm{mm}^{2}$

図-17 熱処理試験体の疲労破面

$\Delta \sigma_{f}=150 \mathrm{~N} / \mathrm{mm}^{2}$ での疲労破壊の起点はフランジコーナー 部の近傍であった。一方, $\Delta \sigma_{w}=100 \mathrm{~N} / \mathrm{mm}^{2}, \Delta \sigma_{f}=150 \mathrm{~N} / \mathrm{mm}^{2}$ では，主桁ウェブ側止端部からき裂が発生し，破断に至 った（図-17(b)）。文献4）の不等脚試験体では，熱処 理試験体を使った同じ試験条件で横桁フランジコーナー 部から破断している. 横桁フランジコーナ一部の応力集 中を考えると，等脚形状よりも主桁ウェブ側に長い不等 脚形状の方が応力集中係数は大きくなる. 逆に，主林ウ エブ側止端部では，図-6に示すように主桁ウェブ側に長 い不等脚形状よりも等脚形状の方が応力集中係数は大き くなる.このような理由から，今回のLP試験体では主 桁ウェブ側止端部から破断したと推測できる.

熱処理試験体（LP）の疲労試験結果を表-8に, 疲労 寿命と主桁・横桁応力比 $\gamma$ (主桁ウェブ応力範囲／横桁 フランジ応力範囲）の関係を図-18に示す. 図中には, 比較のために, 文献4) の結果（板厚 : $9 \mathrm{~mm}$, 主桁ウェ ブ側の脚長 : $11.9 \mathrm{~mm}$ ，横林フランジ側の脚長 : $8.2 \mathrm{~mm}$ ) も示している. 文献4)での結果（不等脚の溶接形状の試 験体），LP試験体（等脚の溶接形状）の結果，いずれ の場合も，横桁フランジ側止端部の疲労寿命は主桁・横 桁応力比が高くなるにしたがって減少している. また, 等脚の試験体（LP）で得られた疲労寿命の主桁・横桁 応力比に伴う変化は，不等脚の試験体よりも小さくなっ ている. 図-11によれば，脚長比 $H_{f} / H_{w}$ が小さいほど，つ まり溶接形状が主桁ウェブ側に長い不等脚であるほど疲 労寿命に対する2軸応力の影響は大きいということを示
表-8 疲労試験結果 (熱処理試験体)

\begin{tabular}{|c|c|c|}
\hline $\begin{array}{c}\text { 主椼ウェブ } \\
\text { 応力範囲 } \\
\left(\mathrm{N} / \mathrm{mm}^{2}\right)\end{array}$ & $\begin{array}{c}\text { 横桁フランジ } \\
\text { 志力範囲 } \\
\left(\mathrm{N} / \mathrm{mm}^{2}\right)\end{array}$ & $\begin{array}{c}\text { 疲労寿命 } \\
\text { (万回) }\end{array}$ \\
\hline 0 & 150 & 83.2 \\
\hline 0 & 150 & 425.0 \\
\hline 50 & 150 & 203.6 \\
\hline 50 & 150 & 111.5 \\
\hline 100 & 150 & 79.2 \\
\hline
\end{tabular}

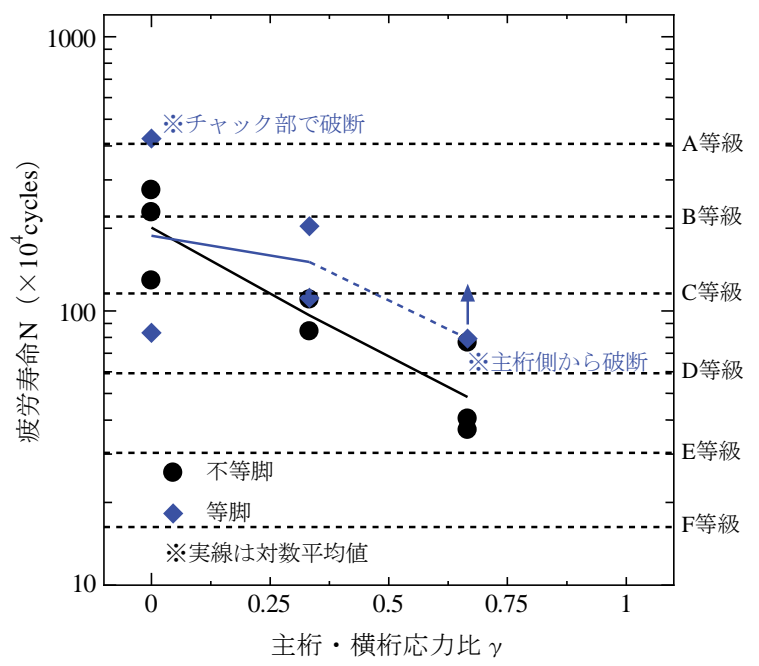

図-18 疲労寿命一主桁 ・横林応力比関係

しており，これは本疲労試験結果とも対応している.

なお，LP試験体の主桁・横林応力比が0での疲労寿命 のばらつきが他の主桁・横桁忘力比での疲労寿命と比べ て大きくなっているが，これはこの状態での応力範囲が 疲労限に近くなったためとも考えられるが，その詳細は 現在のところ不明である.

\section{(5) 疲労試験結果と計算値の比較}

2章で提案した補正係数の算出式の妥当性を確認する ために，補正係数から推定した疲労寿命と疲労試験結果 を比較した. なお，各主桁・横桁応力比の疲労寿命は， 疲労寿命が応力範囲の3乗に反比例すると仮定し, 主 枌・横枌応力比 0 での疲労寿命の平均值から算出してい る.

その結果を図-19に示す. 疲労試験結果にばらつきが あるものの, 推定結果は主桁・横桁応力比による疲労寿 命の変化の様子をほぼ再現している.

\section{4. 疲労寿命評価法の提案}

これまでの研究成果と本研究での検討結果を基に，交 差部の疲労寿命評価法を以下のように提案する. 


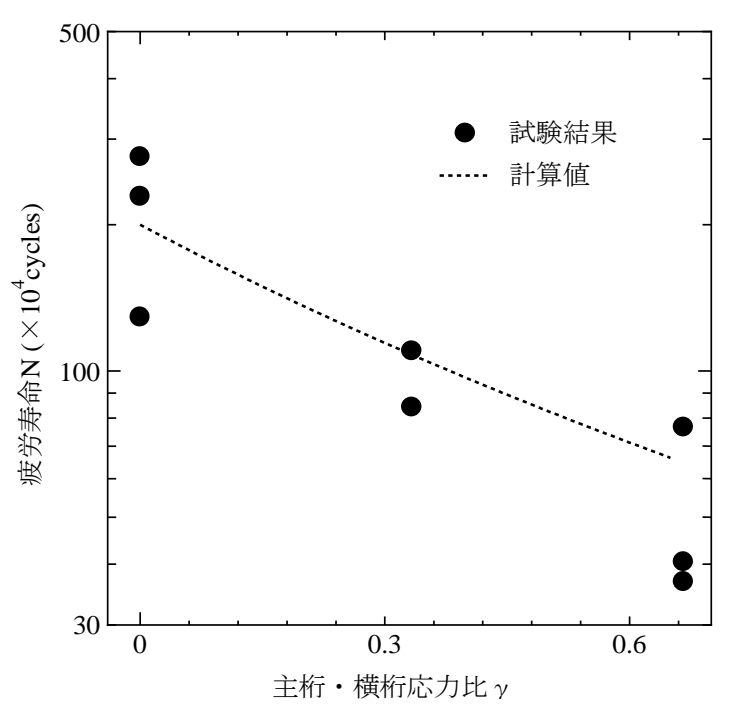

(a) 不等脚試験体

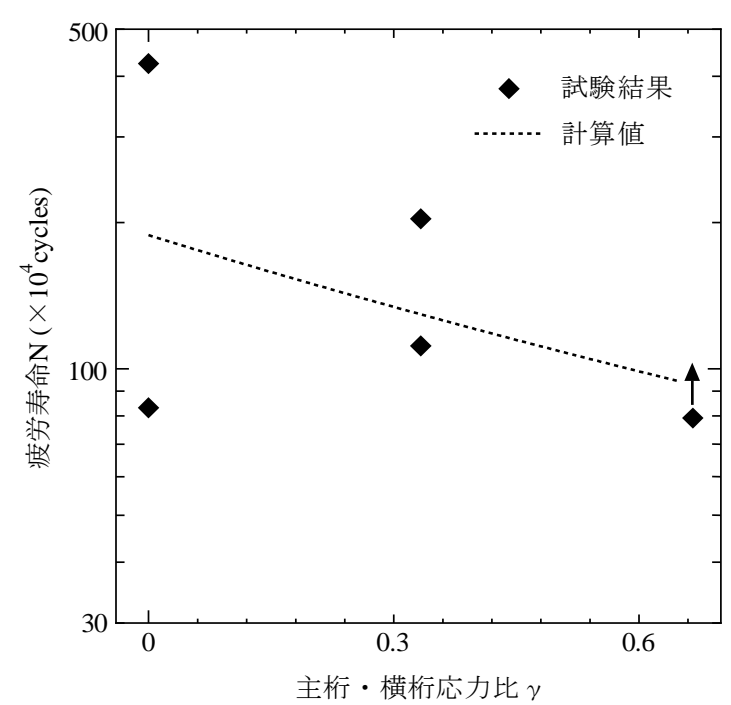

(b) 等脚試験体

図-19 疲労試験結果と計算值の比較

\section{（1）主桁ウェブ側溶接止端部を破壊起点とする場合の疲 労寿命評価法}

横桁フランジに作用する力あるいは応力により主桁ウ エブ側溶接止端に生じる応力は増加するものの, 横桁フ ランジの公称応力が主桁ウェブの公称応力と同じであっ ても，その増加は20\%程度以下にすぎない，また，横桁 フランジ応力による疲労寿命の変化は明確ではない，そ のため, 主桁ウェブの公称応力範用を用い, 疲労強度等 級をJSSC指針で定められているGとして疲労寿命評価を 行う.

\section{（2）横桁フランジ側溶接止端部を破壊起点する場合の疲 労寿命評価法}

主桁ウェブに作用する力あるいは応力による横桁フラ ンジ側溶接止端の応力の変化は著しい. 主桁ウェブに横 桁フランジと同じ大きさの公称応力が作用した場合, 最 大で80\%程度の応力増加が生じるため，これを考慮する 必要がある.また，疲労試験においても，主桁ウェブ応 力による顕著な疲労寿命の減少が認められた.

横桁フランジの公称応力範囲に式(4)で与えらる応力 増加係数を乗じて公称応力範囲を補正する. 補正した応 力範囲を用い, 疲労強度等級をJSSC指針で定められて いるE等級として疲労強度評価を行う。なお，溶接止端 の非仕上げ，仕上げで区別する場合には，一般に止端部 を仕上げれば止端曲率半径を3.0mmは確保できることか ら，k $k_{5}$ 1.0（非仕上げ），0.85（仕上げ）とすることも 考えられる.

\section{5. まとめ}

主桁ウェブ・横桁フランジ交差部の疲労強度に対する 2軸応力および板厚と溶接形状の影響を明らかにし，交 差部の疲労寿命評価方法を提案することを目的として, 有限要素応力解析と疲労試験を行った. 本研究で得られ た主な結果は以下のとおりである.

1) 主桁ウェブ応力と横桁フランジ応力が等しい場合, 主桁ウェブ側止端部の応力は1軸応力状態と比べて5 〜20\%増加するのに対し, 横桁フランジコーナー部 は20〜80\%増加する。

2) 応力増加係数に対して面取り半径の影響は小さいが, 板厚, 溶接脚長, 止端半径の影響は無視できない.

3) 横析フランジコーナ一部の応力集中と応力増加係数 は, 主桁ウェブが薄く, 横桁下フランジが厚い板の 組合せで脚長が横桁フランジ側に長く, 止端半径が 大きい溶接形状であれば小さくなる

4) 主析ウェブ側止端部の疲労強度に対する2軸応力の 影響は, 横桁フランジ側止端部の疲労強度に比べて 小さい.

5) 2軸応力の影響, 溶接形状（脚長比），板厚を考慮 した交差部の疲労寿命評価法を提案し，その妥当性 を実験結果と比較することにより確かめた.

ここでは，主桁ウェブと横桁フランジの 2 方向から力 あるいは応力が作用する場合を対象として, 交差部の疲 労強度評価法について検討した結果を示した. ただし， 実際の交差部では，横桁フランジだけではなく横桁ウェ ブも主桁ウェブに接合されている. また, 当該部分の主 桁ウェブ部にはせん断応力が生じ，その向きは荷重の移 動に伴い変化する. 以上のような交差部の特徵を加味し 
たより合理的な疲労強度評価について検討を進めるべき と考えている．なお，検討結果の一部についてはを既に 公表している》.

謝辞 : 本研究は科学研究費補助金基盤研究(B)（課題番 号 : 19360208）の補助を受けて行ったものである.ここ に記して深謝します。

\section{参考文献}

1) 日本道路協会 : 鋼橋の疲労, 丸善, 1997.

2) 平山繁幸，森猛 : 横桁フランジが交差する主桁ウェブ溶接
部の疲労強度に対する 2 軸荷重の影響, 土木学会論文集, No.745/I-65, pp.121-130, 2003.

3）平山繁幸, 森猛: 試験体形状の異なる十字溶接継手の疲労 強度に関する検討，溶接学会論文集，Vol.25，No.2, pp.268277, 2007.

4) 森猛, 平山繁幸, 鴫原志保 : 主桁ウェブに接合された横桁 フランジ溶接部の疲労強度に対する 2 軸荷重の影響, 土木 学会論文集 A, Vol.63，No.1，pp.56-65， 2007.

5) 本道路協会 : 道路橋示方書・同解説, 丸善, 2002.

6) 日本鋼構造協会 : 鋼構造物の疲労設計指針・同解説，技報 堂出版, 1993.

7) 平山繁幸, 森 猛, 望月建志 : 主応力方向が変化するウェブ ガセット溶接継手部の疲労強度評価, 構造工学論文集, Vol.51A, pp.1027-1036, 2005.

(2010.9. 21 受付)

\section{FATIGUE STRENGTH EVALUATION METHOD FOR WELDED JOINTS BETWEEN MAIN GIRDER WEB AND LATERAL GIRDER FLANGE CONSIDERING INFLUENCE OF BI-AXIAL FORCE}

\section{Takeshi MORI, Shigeyuki HIRAYAMA and Takuya KAGAWA}

Welded joints between main girder web and lateral girder flange in girder type steel bridges are usually subjected to bi-axial stresses which are stress on the web and stress on the flange. In this study, for the purpose of obtaining the estimation formula for fatigue strength of the welded joints considering influence of bi-axial force, 3-D FEM stress analyses and fatigue tests have been performed on model specimens with various weld shapes and plate thickness. In this formula, stress increment due to bi-axial force has been paid attention. The estimation formula could simulate the tendency of the fatigue test results. 